\title{
An Evaluation and Comparison of Water Quality between Urban and Peri-urban River Reaches
}

\author{
Laura Kusari ${ }^{*}$ \\ 10000 Prishtine, Kosove \\ Accepted 10 Dec 2016, Available online 16 Dec 2016, Vol.6, No.6 (Dec 2016)
}

†Department of Hydrotechnics, Faculty of Civil Engineering and Architecture, University of Prishtina "Hasan Prishtina", Bregu i Diellit, p.n.,

\begin{abstract}
The process of urbanization is more intense and is causing more changes in environment. As a result of urbanization, surface waters are deteriorated, in terms of their hydrological changes as well as its water quality impacts. This paper is focused in the research of water quality changes as a result of catchment's urbanization. The river reaches selected for this project were Prishtevka and Gracanka Rivers. For those rivers, grab sampling was performed in three cross sections of each one, starting from the upper river reach, in the middle and the last cross section in the lower river reach. The outcome of this research was achieved after the laboratory analyses of those water samples for main water quality constituents such as: Dissolved Oxygen, Electrical Conductivity, Turbidity, Total Suspended Solids and Biological Oxygen Demand. The laboratory results showed that urban reaches of Prishtevka and Gracanka experience an increase in almost all constituents, but mostly in oxygen demand, conductivity, turbidity and total suspended solids. The results revealed that the quality of surface waters of Prishtevka and Gracanka Rivers is deteriorated step by step as those rivers are approaching and flowing through out urbanized areas.
\end{abstract}

Keywords: Water Quality, Urbanization, Urban, Peri-urban, River.

\section{Introduction}

The process of urbanization is becoming more and more intense as for the first time in the 200 year the half of the world's population is located in urban and peri-urban areas. It is estimated that this number will increase to 9,6 billion by the year 2050, with most of the growth occurring on the edges of mega cities, although smaller cities are also undergoing large transformations (World watch Institute, 2013).

On the other hand, the anthropogenic activities within catchment are contributing to the changes in land use from forested and agricultural one to urban land use. Land use changes in those areas affect the catchment itself. Those changes are directly responsible for the quantitative and qualitative changes in river flowing through the same catchment The great majority of rivers in the world are impacted by urbanization, primarily by increased impervious surface that alters the hydrological regime (Konrad \& Booth, 2005) (Walsh, 2005). The increased urbanization impacts changes in river flow rate, the amount of sediments in streams and causes many stream morphological processes. The magnitude of these changes is the result of the spatial arrangement of urbanization (Caro- Borrero, et al., 2015; Jacobson, 2011).

*Corresponding author: Laura Kusari, DOI: https://doi.org/10.14741/ijcet/v.6.6.32
Urbanization, as a cause of many other processes doesn't show up during a night but is a long process taking place in phases.

The first one is a pre-urbanization phase. Land use is sustainable and the streams are in a state of dynamic equilibrium. The second phase is the phase where the development starts and the areas without vegetation are becoming more spread. In this phase, the soil erosion occurs and it can reach up to 40000 times the rate of erosion during pre-urbanization phase (Chin, 2006). This construction time is relatively short compared to the time needed for the stream to improve from this disturbance. The third phase is post construction phase where the urban areas are developed, including houses, roofs, streets, sewage networks and parking lots (Chin, 2006). Soils and vegetation are removed and substituted with impervious surfaces. As a result of the decrease of infiltration rate, the urban runoff is considerably higher (Gregory, 2006).

The numerous impacts of urbanization in the catchment, starting from its second phase, mainly can be divided in physical, chemical and eco- biological impacts. The physical impacts include changes in catchment's hydrology, stream geomorphology and the stream temperature. Chemical impacts of urbanization are far more variable than those hydrological or geo morphological ones. They depend on the type and the 
degree of urbanization, the presence of waste water treatment plants, overflow in the combined sewage network and the presence of storm water network. In general, after urbanization there is an increase in almost all constituents in surface waters (Kusari, 2012).

With the increase of impervious surface and urban runoff from urbanized areas, as well as the waste water discharge, the increase of pollution loads is introduced in stream (Tufford et al., 2003). Those streams that drain urbanized catchments are degraded in the aspect of their water quality and in literature this is known as an "urban syndrome" (Meyer et al., 2005).

\section{Study area}

Kosovo is experiencing a rate of $1430,8 \%$ population growth in urban areas, if we compare statistics for the time period from 1948 - 2001 (Kosovo Environmental Protection Agency, 2008). According to the same source, the number of urban population has increased from $37 \%$ to $44 \%$ only for the period from 1991 to 2001. The population's density has also increased from 62,7 inhabitants $/ \mathrm{km}^{2}$ (1948) to 227 inhabitants $/ \mathrm{km}^{2}$ (2004), and this number is even higher in the area around capital city, where it reaches up to 600 inhabitants $/ \mathrm{km}^{2}$. So, the trend of increasing the urban population and its density is still continuing, thus imposing a greater stress to surface waters. The streams will continue to carry the weight of planned industrial and economic growth of this area, for the 2010 - 2020+ (Kosovo's Spatial Plan, 2010)

For the purpose of this project, the study area was chosen to be the central part of Kosovo. In order to document changes of water quality constituents based upon the area development, two rivers, Prishtevka and Gracanka, with different scale of catchment's urbanization were chosen for analyses.

The Prishtevka River Catchment covers an area of $109,33 \mathrm{~km}^{2}$, and its vegetative cover comprises of primarily arable land $\left(41,68 \mathrm{~km}^{2}\right)$, followed by bushes $\left(38,66 \mathrm{~km}^{2}\right)$, meadows $\left(27,78 \mathrm{~km}^{2}\right)$ and forests $(1,20$ $\mathrm{km}^{2}$ ). Prishtevka River is $25,9 \mathrm{~km}$ long and has an average slope of $1,0 \%$.

On the other hand, Gracanka River Catchment covers an area of $180,93 \mathrm{~km}^{2}$, and its vegetative cover comprises of primarily arable land $\left(71,12 \mathrm{~km}^{2}\right)$, followed by bushes $\left(57,60 \mathrm{~km}^{2}\right)$, meadows $\left(47,41 \mathrm{~km}^{2}\right)$ and forests $\left(4,80 \mathrm{~km}^{2}\right)$. Gracanka River is $21,5 \mathrm{~km}$ long and has an average slope of $1,2 \%$.

Both rivers, while flowing through the catchment are subject to many pollution sources. In urban reaches of the same rivers, the untreated domestic and industrial waste waters are discharged directly into. On the other hand, agriculture, direct damping of solid waste in the vicinity of rivers, erosion and mining activities are all impacting the quality of those rivers. Prishtevka River quality is deteriorated by the direct discharge of domestic waste waters as well as industrial activity from ironmongery, food and textile industry, slaughterhouse etc. Gracanka River is receiving waste waters from untreated domestic sewage as well as waste waters from metallurgical industry.

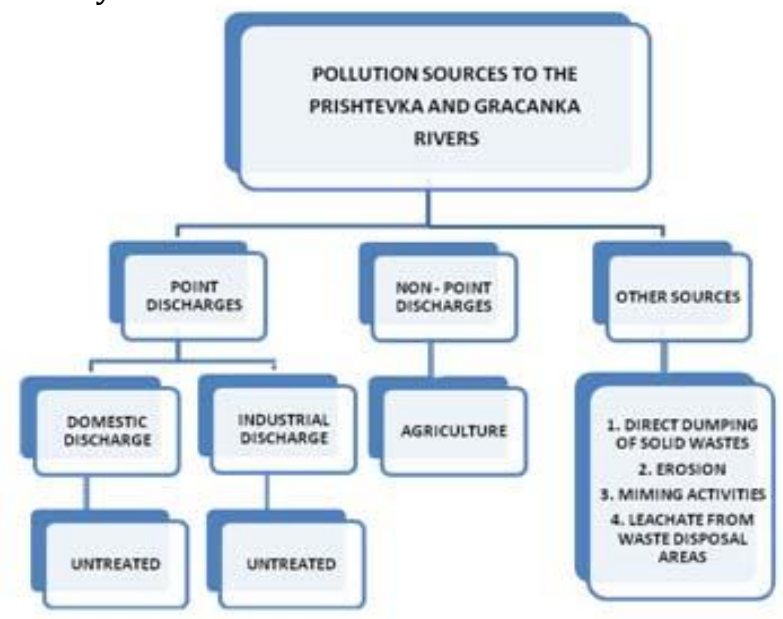

Fig. 1 Pollution sources to Prishtevka and Gracanka Rivers

The sampling locations were chosen on the upper part of the river reaches, areas less urbanized and on the lower part of the same rivers, areas experiencing extensive urbanization. On the other hand, urban sites had residential or industrial development in their vicinity. According to those criteria, 6 locations were chosen as described.

Table 1 Description of sampling locations

\begin{tabular}{|c|c|c|}
\hline Sampling Point & River & Sampling Site Description \\
\hline SP I & Prishtevka & Upper part of Prishtevka \\
SP II & Prishtevka & Middle part of Prishtevka \\
SPIII & Prishtevka & Lower part of Prishtevka \\
SP IV & Gracanka & Upper part of Gracanka \\
SP V & Gracanka & Middle part of Gracanka \\
SP VI & Gracanka & Lower part of Gracanka \\
\hline
\end{tabular}

\section{Methods}

Water samples of $1000 \mathrm{ml}$ each, were collected from 6 above mentioned locations, with the help of sampling rod. At each cross section, three sampling verticals were set, the first one near the left river bank, the second one in the middle of the river reach and the third one near the right river bank. On the each sampling site, at each cross section, sampling was done approximately $30 \mathrm{~cm}$ below the water surface. The water samples collected were labeled with the time, date and sampling site and were sent to the laboratory and tested for the following water quality parameters: Dissolved Oxygen (DO), Electrical Conductivity (EC), Turbidity (TTU), Total Suspended Solids (TSS), and Biological Oxygen Demand (BOD).

\section{Results and Discussion}

The laboratory analyses of the taken grab samples revealed the following results, for the rivers Prishtevka and Gracanka. 
Table 2 Results of Prishtevka River Sample Analyses

\begin{tabular}{|c|c|c|c|c|c|}
\hline Parameter & Sym. & Unit & $\begin{array}{c}\text { Upp } \\
\text { reach }\end{array}$ & $\begin{array}{c}\text { Midd } \\
\text { reach }\end{array}$ & $\begin{array}{c}\text { Low } \\
\text { reach }\end{array}$ \\
\hline Dissolved Oxygen & DO & $\mathrm{mg} / \mathrm{l}$ & 8,01 & 1,83 & 6,37 \\
\hline $\begin{array}{c}\text { Electrical } \\
\text { Conductivity }\end{array}$ & $\mathrm{EC}$ & $\begin{array}{c}\mathrm{mSc} \\
\mathrm{m}\end{array}$ & 808 & 820 & 798 \\
\hline Turbidity & $\mathrm{TTU}$ & $\mathrm{NTU}$ & 16,7 & 54,0 & 79,8 \\
\hline $\begin{array}{c}\text { Total Suspended } \\
\text { Solids }\end{array}$ & $\mathrm{TSS}$ & $\mathrm{mg} / \mathrm{l}$ & 16,6 & 127,0 & 196,0 \\
\hline $\begin{array}{c}\text { Biological Oxygen } \\
\text { Demand }\end{array}$ & $\mathrm{BOD}$ & $\mathrm{mg} / \mathrm{l}$ & 3,1 & 17,4 & 128 \\
\hline
\end{tabular}

\subsection{Dissolved Oxygen}

Dissolved Oxygen values in the upper part of both rivers were relatively high, for Prishtevka it was 8,01 $\mathrm{mg} / \mathrm{l}$ and for Gracanka it was $8,80 \mathrm{mg} / \mathrm{l}$.

Although dissolved oxygen values were relatively high (all above $5 \mathrm{mg} / \mathrm{l}$, a value considered to be necessary for biological community) on the peri-urban streams, this study did not evaluate the seasonal variation of DO. Also, based on the laboratory analyses it is evident that DO generally decreases downstream, with values as low as $1.83 \mathrm{mg} / \mathrm{l}$ for Prishtevka's middle reach.

\subsection{Electrical Conductivity}

Increase in conductivity is most consistently documented water quality change associated with urbanization. If we compare conductivity values, we can notice that the conductivity increases towards urbanized areas in the catchment, suggesting increased dissolved elements in the urban river reach.



Fig. 2 The measurement of Electrical Conductivity

According to the lab analyses (shown in the tables 2 and 3), the values in peri-urban river reaches (Gracanka $587 \mu / \mathrm{cm}$; Prishtevka $808 \mu / \mathrm{cm}$ ) are relatively lower than those in urban river reaches (Prishtevka $820 \mu / \mathrm{cm}$; Gracanka $1592 \mu / \mathrm{cm}$ ) possibly due to higher urban influence. Significant changes in conductivity measurements can indicate contamination from point and non - point sources of pollution.

\subsection{Turbidity}

As for the turbidity values, the results show very low values on the peri-urban river reach (16.7 NTU for Prishtevka River; 11.3 NTU for Gracanka River), but those values are relatively higher on the urban reaches of the same rivers (79.8 NTU for Prishtevka and 48.7 NTU for Gracanka River).

Table 3 Results of Gracanka River Sample Analyses

\begin{tabular}{|c|c|c|c|c|c|}
\hline Parameters & Sym. & Unit & $\begin{array}{c}\text { Upp } \\
\text { reach }\end{array}$ & $\begin{array}{c}\text { Midd } \\
\text { reach }\end{array}$ & $\begin{array}{c}\text { Low } \\
\text { reach }\end{array}$ \\
\hline Dissolved Oxygen & DO & $\mathrm{mg} / \mathrm{l}$ & 8,80 & 6,70 & 7,11 \\
\hline $\begin{array}{c}\text { Electrical } \\
\text { Conductivity }\end{array}$ & $\mathrm{EC}$ & $\begin{array}{c}\mathrm{mSc} \\
\mathrm{m}\end{array}$ & 587 & 1592 & 747 \\
\hline Turbidity & $\mathrm{TTU}$ & $\mathrm{NTU}$ & 11,3 & 48,7 & 16,6 \\
\hline $\begin{array}{c}\text { Total Suspended } \\
\text { Solids }\end{array}$ & $\mathrm{TSS}$ & $\mathrm{mg} / \mathrm{l}$ & 8,8 & 81,0 & 18,2 \\
\hline $\begin{array}{c}\text { Biological Oxygen } \\
\text { Demand }\end{array}$ & $\mathrm{BOD}$ & $\mathrm{mg} / \mathrm{l}$ & 1,3 & 33,5 & 9,6 \\
\hline
\end{tabular}

\subsection{Total Suspended Solids}

Regarding the total suspended solids, their value in urban part of the river Prishtevka is 196 (mg/l) and this value is as higher as 7 fold value of the same for peri-urban reach of Prishtevka River (16.6 mg/l). Those values for Gracanka River, peri -urban and urban reach are $8,8 \mathrm{mg} / \mathrm{l}$ and $81,0 \mathrm{mg} / \mathrm{l}$.

This can be explained by the discharge of untreated waste water in the rivers and also by land use changes in their catchments (since the TSS is an indicator of erosion and sediment transport in streams).

\subsection{Biological Oxygen Demand}

The highest BOD values are noticed in the urban stream Prishtevka (128 mg/l) and followed by the Gracanka urban reach value of $33,5 \mathrm{mg} / \mathrm{l}$, probably due to the waste water discharge in these locations. Increased biological oxygen demand (BOD) in the urban part of the streams suggests increased organic matter, as a result of wastewater discharge and the ability of stream's self-purification.

So, the direct discharge of untreated domestic sewage into the urban reaches of rivers is directly responsible for the high organic pollution, thus leading to very high BOD values in those sites.

\section{Conclusions}

An increase of impervious surface of the studied River's reaches, due to urbanization, results in an increase of all analyzed water quality parameters, in the lower part of Prishtevka and Gracanka rivers.

Prishtevka River is the major recipient of all waste waters and an end point for organic substances of domestic effluents. In the upper reach of Prishtevka River, the flow rate is relatively low, but water seems 
very clear and no odor is present. On the other hand, as the Prishtevka River flows through more urbanized areas, flow rate is higher; the water has a dark color and bad odor, probably due to sewage effluent discharge. The same was noticed for the Gracanka River, too. Its quality in the peri-urban reach differs a lot from an urban reach of the river

To summarize, the main threats to the quality of those streams are untreated sewage system, industrial point sources, erosion, solid wastes, agricultural activities and land use changes in their catchments. Therefore, the quality of surface waters of Prishtevka and Gracanka rivers is deteriorated step by step as those rivers are approaching and flowing through out urbanized areas.

The laboratory results revealed that urban reaches of Prishtevka and Gracanka experience an increase in almost all constituents, but mostly in oxygen demand, conductivity, turbidity and total suspended solids.

Concentrations of nutrients and values of field parameters in urban river reaches selected for this research are affected by the amount of urbanization in this area. The results show that urbanization is adversely impacting the water quality of the rivers included in this research.

\section{References}

Worldwatch Institute (2013), World Population: Fertility Surprise Implies More Populous Future, http://vitalsigns.worldwatch.org/vs-trend/worldpopulation-fertility-surprise-implies-more-populousfuture., Accessed: 26/10/2016.

Konrad, Christopher and Booth Derek, (2005), Hydrologic changes in urban streams and their ecological significance. s.l., s.n., pp. 157-177.
Walsh, Ch., et al., (2005), The urban stream syndrome: current knowledge and the search for a cure, Journal of The North American Benthological Society, 24(3):706-723.

Jacobson, C., (2011) Identification and quantification of hydrological impacts of imperviousness in urban catchments; a review, Journal of Environment Management, Volume 92, pp. 1438-1448.

Caro- Borrero, A., Carmona, J. J., Gonzales, M. T. \& Mazari, H. M., (2015), Hydrological evaluation of a peri-urban stream and its impact on ecosystem services potential, Global Ecology and Conservation, Volume 3, pp. 628-44.

Chin, Anne, (2006), Urban Transformation of river landscape in a global context, Journal of Geomorphology, Elsevier.

Gregory, J.H. et al., (2006), Effect of urban soil compaction on infiltration rate, Journal Of Soil and Water Conservation, vol 6, nr. 3.

Kusari, Laura, (2012), Surface water quality changes of river reaches due to urbanization, Water Resources and Wetlands, Conference Proceedings.

Tufford, Daniel et al., (2003), Impacts of urbanization on nutrient concentrations in small southeastern coastal streams, Journal of the American Water Resources Association.

Meyer, SC, (2005), Analysis of base flow trends in urban streams, northeastern Illinois, USA. Hydrogeology Journal 13(5-6):871-885.

A report of Environment situation (2006-2007), (2008). Kosovo's Agency for Environment Protection

http://www.ammkrks.net/repository/docs/2StateofEnviron ment.pdf.

Plani hapesinor i Kosoves. Strategjia e zhvillimit hapesinor 2010-2020+ (2010), Ministria e Mjedisit dhe Planifikimit Hapesinor, Prishtine. 